\title{
Janelas abertas: música, política e sociabilidade em uma entrevista com Cynara
}

\author{
Daniel Lopes Saraiva* \\ ORCID iD 0000-0002-8409-2314 \\ Pesquisador Independente, Belo Horizonte, Brasil
}

\author{
Adrianna Setemy* \\ ORCID iD 0000-0002-6213-5088 \\ Universidade Salgado de Oliveira, Programa de Pós-Graduação em História, Rio de Janeiro, Brasil
}

\section{Diego Knack*}

ORCID iD 0000-0001-9860-6403

Pesquisador Independente, Natal, Brasil

\begin{abstract}
Resumo: A música brasileira vem sendo debatida nas últimas décadas pela historiografia. Um debate profícuo que tem por vezes saído dos muros acadêmicos e atingido um público mais abrangente. A História Oral tem ajudado nesse debate ao apresentar as narrativas de atores que fizeram parte da história da música brasileira, como é o caso da cantora Cynara. Ao abrir suas memórias e narrar sua trajetória artística, Cynara nos possibilita ver pontos da trajetória de uma artista que tem trabalhado nas últimas décadas fazendo arte. Seu depoimento começa na infância, na Bahia, e chega até os trabalhos mais recentes. É um depoimento onde podemos observar de que forma a cantora se posiciona enquanto artista, suas redes de sociabilidades durante a trajetória e parte do caminho seguido pela artista.
\end{abstract}

Palavras-chave: Música. Quarteto em Cy. Festival. Repertório. Memória.

Doutor em História do Tempo Presente pelo Programa de Pós-Graduação em História da Universidade do Estado de Santa Catarina (Udesc). Com orientação da Profa. Dra. Mariana Joffily. E-mail: danielsaraiva_15@hotmail.com.

* Doutora em História Social pelo Programa de Pós-Graduação em História da Universidade Federal do Rio de Janeiro (UFRJ). Com orientação da Profa. Dra. Maria Paula Araújo. E-mail: asetemy@gmail.com.

* Doutor em História Social pelo Programa de Pós-Graduação em História da Universidade Federal do Rio de Janeiro (UFRJ). Com orientação do Prof. Dr. Carlos Fico. E-mail: dk.historia@gmail.com. 


\title{
Open windows: music, politics and sociabilities in an interview with Cynara
}

\begin{abstract}
Historiography has debated brazilian music over the last few decades. A fruitful debate which at times escaped the academic walls and reached a broader audience. Oral History has aided this debate by showing narratives from actors which were part of brazilian music history, as is the case of the songstress Cynara. By sharing her memories and telling her artistic path, Cynara allows us to see points of the trajectory an artist which worked the last few decades producing art. Her testimony begins with her childhood, in Bahia, and goes up to more recent work. From her testimony we can see the way she her positioning as an artist, her sociability network during her journey and the path she followed.
\end{abstract}

Keywords: Music. Quarteto em Cy. Festival. Repertoire. Memory.

A música brasileira é sem dúvida uma tradutora de muitos dos nossos dilemas sociais e políticos; através dela podemos recontar diversos momentos da história do Brasil. Mas as cançóes, movimentos musicais e os seus sujeitos também têm incríveis histórias. Cynara é uma dessas personagens cuja vida está tão atravessada por música, quanto por momentos emblemáticos do passado recente. A entrevista com a artista foi realizada em 27 de julho de 2018 na casa da cantora, localizada na Barra da Tijuca, no Rio de Janeiro. Durante mais de uma hora de gravação, a artista narra sua trajetória artística, desde a infância musical na Bahia até a chegada ao Rio de Janeiro. Cynara relata aspectos pouco conhecidos da formaçáo do Quarteto em Cy apadrinhado por Vinicius de Moraes, fala sobre as diversas gravaçóes realizadas pelo grupo e das participaçôes em festivais, com destaque para o III Festival Internacional da Canção (FIC), em 1968. Também são relembrados colegas do meio artístico que ainda estáo entre nós, e outros que já não podem recontar suas trajetórias. Trata-se do testemunho emocionado de quem trabalha com arte há mais de meio século. ${ }^{1}$

Aos 76 anos Cynara pode ser considerada uma referência para entendermos parte da história da nossa música. Ao lado das irmás, Cyva, Cybele e Cylene, formou o Quarteto em Cy em 1963. Ainda meninas, participaram do projeto Hora da Criança, idealizado e dirigido pelo professor Adroaldo Ribeiro Costa, que apresentava um programa educacional com o mesmo nome na Rádio Sociedade da Bahia. No projeto, as crianças participavam de aulas de canto, dança e teatro, realizavam apresentaçóes e tinham, muitas vezes, seu primeiro contato com obras de autores famosos, como Monteiro Lobato. Ainda em Salvador, Cynara fez apresentaçóes ao lado da irmã Cylene em programas da TV Itapuã. Em meados de 1962, Cyva, a irmã mais velha e já formada em Letras Clássicas, muda-se para o Rio de Janeiro. Professora de português em

1 O título "Janelas abertas" faz referência a uma canção de Tom Jobim e Vinicius de Moraes gravada pela primeira vez em 1959, pela cantora Sylvia Telles. A canção foi gravada pelo Quarteto em Cy no disco de 2016, sendo a música que nomina ao disco. 
colégios estaduais e particulares, a primeira Cy não deixa a música de lado e participa de programas de calouros como Papel carbono, de Renato Murce, na Rádio Nacional. Vislumbrando uma carreira musical junto às irmãs e depois de circular por ambientes que se tornariam conhecidos pela efervescência musical, Cyva consegue trazê-las para a cidade maravilhosa (Saraiva, 2021).

Em 1963, o grupo participou da trilha sonora do filme Sol sobre a lama, de Alex Vianny. A indicação para esse trabalho veio de Vinicius de Moraes, encantado com a voz de Cyva e ainda mais entusiasmado ao ver as quatro irmás juntas. $\mathrm{O}$ poeta compôs as letras das cançóes do filme, enquanto Pixinguinha é o autor das músicas. Além de apadrinhado por Vinicius de Moraes, o Quarteto em Cy também contou com o acolhimento de Carlos Lyra, que batizou o grupo. As irmás logo despontaram na cena artística.

No ano de 1964, o Quarteto em Cy lança seu primeiro disco pelo selo Forma, produzido por Roberto Quartin e com músicas de Edu Lobo, Ruy Guerra, Carlos Lyra, Vinicius de Moraes, Sérgio Ricardo e Tom Jobim, entre outros compositores que consolidariam futuramente a sigla MPB. Até 1968, o Quarteto teve agenda cheia, incluindo o lançamento de diversos discos como Vinicius e Caymmi no Zum Zum (1965), Som definitivo, com Tamba Trio (1966) e De Marré de Cy (1967), lançados pelos selos Forma e Elenco. O Quarteto também participou do disco que se converteu em um dos grandes marcos da música brasileira, Os Afro-sambas (1965), de Vinicius e Baden Powell. Durante a carreira foram mais de trinta discos lançados.

A primeira mudança na formação do grupo ocorre em 1966: Cylene engravida e entre a vida artística e a maternidade, a cantora escolhe a segunda. Desde entáo o grupo teve diferentes formaçóes, com pausas e continuidades. Em 1967, o Quarteto recebe proposta para passar dois anos nos Estados Unidos. Cynara e Cybele não aceitam. Em nome da permanência do grupo, Cyva e Aloysio de Oliveira decidem procurar duas cantoras para substituí-las: Sônia e Semíramis. Enquanto o Quarteto segue com nova formação rumo aos EUA, Cynara e Cybele formam uma dupla no Brasil. Em 1967, elas defendem, no II Festival Internacional da Canção (FIC), a música Carolina, de Chico Buarque. A canção conquista o terceiro lugar e estoura, figurando até início de 1968 entre os compactos simples mais vendidos segundo o Instituto Brasileiro de Opiniāo Pública e Estatística (Ibope).

Mas o ano de 1968 reserva ainda mais emoçóes. Entre setembro e outubro, elas participam do III Festival Internacional da Canção (FIC). A música defendida é Sabiá, parceria de Chico Buarque e Tom Jobim. Ao serem anunciadas como vencedoras, as irmãs recebem uma vaia homérica no Maracanãzinho. O público faz coro por outra favorita, a canção Pra não dizer que não falei das flores, de Geraldo Vandré. Vencida a etapa nacional, Sabiá também vence a etapa internacional. E apesar do constrangimento das vaias, o compacto simples com a faixa vencedora entra para os mais vendidos. No mesmo ano a dupla lançaria seu único Long Play, pela CBS, intitulado Cynara e Cybele. 
Mesmo com todo sucesso alcançado e a visibilidade da dupla, Cybele resolve ir para os EUA e se junta ao Quarteto em Cy.

Em 1969, Cynara, sozinha no Brasil, grava seu único disco solo, Pronta para Consumo, lançado pela Elenco. Um disco que a própria artista classifica como coletivo. Com produção de Sidney Miller e participação de Ruy Faria e Renato Corrêa na concepçáo, o disco tem entre os compositores Guarabyra, Chico Buarque, Caetano Veloso, Danilo Caymmi e os próprios Ruy, Sidney e Renato. Cynara é compositora de duas canções do disco, Sem direção, ao lado de Ruy, e Oração do astronauta com Ruy e Sidney. No ano de 1972 o Quarteto retorna ao Brasil com Cyva, Sônia, Cynara e Dorinha Tapajós - as três primeiras fazem parte da formaçáo atual do grupo.

Daphne Patai (2010, p. 142) destaca que a "história oral não serve apenas para nos apresentar fascinantes relatos subjetivos, embora este seja um de seus maiores e duradouros atrativos. Ela é capaz de chamar atenção para a vida de seus narradores e as sociedades nas quais estas vidas são vividas". A história oral, segundo a autora, nos permite expandir os horizontes do nosso conhecimento sobre o mundo. Como afirma Alessando Portelli (2016, p. 18): "A memória, na verdade, não é um mero depósito de informaçóes, mas um processo contínuo de elaboraçáo e reconstruçáo de significado". Para além de sua história individual e a do grupo Quarteto em Cy, o relato de Cynara chama atenção para um período de efervescência cultural que, ao mesmo tempo, foi atravessado por uma ditadura militar e pela onipresença da censura.

A entrevista, que teve uma parte editada e divulgada em três vídeos no site História da Ditadura, ${ }^{2}$ aparece aqui na íntegra. Como cantara o Quarteto em Cy na música Querelas do Brasil "O Brazil não conhece o Brasil/ O Brasil nunca foi ao Brazil”. As lembranças de Cynara são também um convite a esse mergulho nas camadas históricas do Brasil e da música brasileira.

\section{Entrevista}

Daniel Lopes Saraiva - Primeiro eu gostaria que você falasse um pouco das suas influências musicais, do que você ouvia na Bahia.

Cynara - Na Bahia era uma coisa totalmente diferente do que acontece hoje na carreira da gente, as músicas eram folclóricas, eram músicas infantis. O quarteto inicial era composto pelas quatro irmãs: Cyva, Cybele, Cynara e Cylene. Nós frequentamos uma organização, que hoje seria, vamos dizer, uma ONG [Organização Não Governamental], mas era uma organização sem fins lucrativos e que também não recebia dinheiro de lugar

2 Disponível em: https://www.youtube.com/watch?v=Xwv103pAqBs. Acesso em: 10 jun. 2021. 
algum, não era patrocinada por ninguém, era uma coisa espetacular chamada Hora da Criança, do professor Adroaldo Ribeiro Costa, que era um professor de História. Também participava o maestro Agenor Gomes, parente de Dias Gomes, inclusive. Com eles, crianças e adolescentes, até 20 anos, 25 anos, no máximo, tínhamos aulas de balé, de música, de teatro, muito teatro. Também tinha uma rádio, a Rádio Sociedade da Bahia, em que havia um programa do Adroaldo, e funcionava todo domingo, às 10h da manhã. Então fazíamos lá rádio teatro. E nos teatros, propriamente, nós encenávamos peças de Monteiro Lobato e peças do próprio Adroaldo. Desse jeito, nós vivemos e convivemos com a arte em tempo integral. Estudávamos no próprio Instituto Normal da Bahia, no colégio Severino Vieira, e depois no Colégio Central Estadual, tudo escola pública, que era uma coisa maravilhosa. $\mathrm{O}$ que eu tenho de conhecimento é daquela época. Eu acho que os cursos que eu frequentei, as escolas que nós quatro frequentamos tinham ensino muito completo, era sensacional. Você não saía de lá tatibitate, você saía da escola sabendo. Tinha uma coisa chamada segunda época, que fazíamos quando não passávamos direto em alguma matéria, só podia ficar em duas, senão perdia o ano. Então não tinha esse negócio de passar a mão na cabeça do aluno porque pagou isso, pagou aquilo, que o aluno não poderia perder o ano. Pode perder até aprender. Então era uma coisa do ensino pelo ensino, conhecimento pelo conhecimento. A escola náo educava, a escola dava conhecimento. Hoje ficam querendo que a escola eduque o filho, não é para educar, quem educa é pai e máe, entende? Minha ideologia é essa, por isso que eu sou contra uma porrada de coisas que existem hoje, essas ideologias baratas, eu falo mesmo, náo tenho papas na língua para falar, eu náo tenho nada a perder falando isso, porque eu sei o que é passar por escolas boas, sem pagar nada e aprender e levar a coisa a sério. Com professores dignos, todos os professores são dignos, mas o que está faltando é uma, vamos dizer, uma gerência disso tudo, entende? Não sei se é o Ministro, não sei quem é, que dê um rumo às escolas brasileiras, porque eu acho que tudo começa pela educação, e esse Brasil da gente não tem educação. E a educação que tivemos através da arte é a mais rica, porque você aprende brincando, mas está aprendendo. Tinha aula de balé, de canto orfeônico. Estudávamos música através de Villa Lobos, eram cançonetas de Villa lobos, fazíamos vocal já naquela época, eram turmas infantis que cantavam em grupo, por isso temos essa sensação de que grupo náo é boi na linha, todo mundo pensando igual, é todo mundo assimilando, absorvendo conhecimento e doando para aquilo que queríamos, que no caso era fazer arte de uma maneira geral. Entáo eu acho que nós devemos muito a esse movimento, a Hora da Criança.

DLS - E quando você resolveu seguir a carreira artística, e as irmãs também?

Cynara - A Cyva, nossa irmã mais velha, era professora, ela fez faculdade de Letras Clássicas; a Cybele fez curso básico de professora; eu parei no terceiro ano clássico, antigamente tinha clássico e científico, o científico levava você a fazer vestibular, o 
clássico era Letras, eu ia fazer jornalismo, acabei não fazendo porque entrou o Quarteto. Foi exatamente em [19]63, quando eu cheguei no Rio, tive que escolher entre o Quarteto ou a escola, então eu parei de estudar. Eu queria fazer aquilo que eu gostava, que era a arte que eu aprendi. Minhas irmâs eram a mesma coisa. É muito simples de explicar, entende? Quando você tem o respaldo de uma escola boa, de um país que, na época, formava pessoas.

DLS - E o Quarteto acontece muito rápido, não é? Fala um pouco desse início.

Cynara - A Cyva veio para o Rio de Janeiro porque ela queria fazer curso de teatro com Adolfo Celi, e era Celi, [Paulo] Autran e Tônia Carrero, em uma companhia de teatro. Ela era louca pelo Rio de Janeiro, porque minha avó falava isso: "ah, o Rio de Janeiro!". Chegou aqui e se apaixonou realmente pela cidade, ficou dando aulas em tudo quanto é escola, Andrews, essas escolas todas aí. Era português, literatura e latim. Ela dizia: "eu quero que vocês venham", chamava as três irmãs, que estudávamos em Salvador, mas morávamos no interior da Bahia, em Ibirataia. Nós viemos em [19]63; eu fui a última a vir. Cheguei bem no final do ano porque eu tinha que fazer segunda época de matemática. Peguei um aviáo, sozinha, eu não sei até hoje como eu consegui, tinha 16, 17 anos. Ficamos na casa de tias, de parentes, meu pai morreu quando eu tinha 10 anos e minha mãe ficou no interior, ela era escrivă de cartório, fazia casamentos. Quando a Cyva resolveu que tínhamos que vir para o Rio, ela já conhecia o Vinícius [de Moraes], através de Carlos Coqueijo da Costa, que era um baiano, e que era muito amigo nosso. Ela disse ao Vinícius: "ah, eu tenho três irmãs, que estão chegando", aí o Vinícius se interessou: "Elas cantam também? Quero conhecê-las". Teve um filme chamado Sol sobre a lama, do Alex Viany, um puta de um diretor de cinema, e a música era do Pixinguinha com letra do Vinícius. Quando o Coqueijo apresentou a Cyva ao Vinícius, ele decidiu: "elas são quatro baianinhas, elas cantam, lindo". E ele nos chamou para fazer a trilha do filme, para fazer coro com um monte de gente. Quando começamos a cantar, o Vinícius ficou louco: "vocês são minhas!". Vê a frase do Vinícius: "não vou dar para ninguém, vocês são minhas". Daí por diante, ele começou a nos estimular: "vocês têm que fazer um grupo, baianinhas, daqui a pouco vocês ficam velhas e esse nome não é legal para continuar carreira". E a gente, assim, estupefatas, todas as quatro, "carreira, que carreira?”. Quatro totais imbecis, vamos dizer assim, não sabíamos nada da vida, chegando no Rio de Janeiro, cidade grande, e um cara do tamanho do Vinícius dizendo que tínhamos que fazer uma carreira! Ninguém entendia. "Vocês vão ver, vamos fazer uma reunião para dar um nome em vocês". Fizeram a tal reunião, ele e o Carlinhos Lyra; foram os dois que colocaram o nome, com um bocado de gente, um bocado de amigos, todo mundo dava um pitaco aqui, outro ali, aí foi o Carlinhos que falou: "por que náo Quarteto em Cy?”, porque as quatro começam com $\mathrm{Cy}, \mathrm{Cy}, \mathrm{Cy}, \mathrm{Cy}$, entáo C-Y, né? "E tem também a sonoridade do cy, que pode ser como a nota musical", aí 
colocaram esse nome, antes disso éramos As Baianinhas do Vinícius. A história inicial é essa, a gente não tinha nada, tínhamos que trabalhar para viver. Cybele e a Cyva, as mais velhas, davam aulas, eu fui trabalhar como secretária numa loja de departamento, a Cylene a mesma coisa, a mais nova, até o momento em que O Quarteto começou a deslanchar, em [19]64.

DLS - Como foi quando vocês receberam o convite da gravadora Forma?

Cynara - Sim, mas antes da Forma, nós fizemos um show no Bottle's Bar, onde estreamos, no Beco das Garrafas, dia 30 de junho de 1964, dia da estreia do Quarteto em Cy. Nesse show, éramos nós e mais um trio, o Copa Trio, com Dom Um Romão, um ícone da bateria nos anos 60, Gusmão no contrabaixo e o pianista era Dom Salvador, que está nos Estados Unidos até hoje. No violáo era Rosinha de Valença e no outro violão era o nosso arranjador, Carlos Castilho, irmão do Bebeto Castilho, do Trio Tamba. Enfim, nós ficamos alguns meses fazendo esse show, antigamente era assim, hoje é um dia e olhe lá. As pessoas gostaram do show. E o pessoal da Forma foi assistir, o Wadi Gebara e o Roberto Quartin. Eles nos disseram que íamos gravar um disco. Isso era tudo pra gente, uma sensação de filme, entende? Vivenciar esse tipo de coisa, ser profissional, não tínhamos noção de nada disso, era tudo muito amador, e a gente gostava disso. O Vinícius fez a nossa cabeça e a gente se jogou no mundo.

DLS - Como é a sua lembrança do Beco das Garrafas?

Cynara - Foi ótimo lá, era um lugar pequenininho, ainda existe hoje. O Beco era muito pequeno, mas foi onde nossa carreira alavancou, foi ali que nós começamos realmente a ser reconhecidas. Mas nós estouramos mesmo com o Zum-Zum, no final de [19]64 para [19]65, e no final de [19]65 para [19]66: duas temporadas, com Vinícius, [Dorival] Caymmi, Quarteto em Cy e o conjunto de Oscar Castro Neves. Foi maravilhoso, porque Vinícius e Caymmi juntos... Aliás, tem uma coisa engraçada desse show, era o Quarteto em Cy e Caymmi, com direção de Aloysio de Oliveira, o Aloysio dizia: "vocês vão fazer um show assim, Bahia, vocês e Caymmi, tudo a ver". Ele marcou um encontro na casa do Caymmi, que ficava em Copacabana, e a gente ficou conversando. O Vinícius soube disso, ele estava chegando de Los Angeles e falou: "nada disso, eu vou entrar nesse show", porque ele já gostava da gente, ele tinha nos descoberto, nos deu um nome, "como vão me deixar de fora?", aí ele entrou no show, fez todas as vinhetas, foi maravilhoso. Estreamos no final de [19]64 para [19]65, e depois no final de [19]65 para [19]66.

DLS - Aí veio o disco emblemático. 
Cynara - Aí veio o disco, fomos gravar. Nós gravamos ao vivo em um estúdio, e não paramos mais.

DLS - Vocês foram contratadas pela Elenco?

Cynara - O Aloysio era o diretor do show e ele decidiu que nós íamos fazer um disco na Elenco. Ele tinha o selo da Elenco e nós gravamos vários discos lá. Em [19]67, viajamos para Los Angeles, e ficamos 6, 7 meses lá; e gravamos um LP, antigamente era LP. Gravamos um aqui, com Caymmi, para a Warner Bros., e gravamos um lá, só a gente, um super disco.

DLS - E como foi a temporada de vocês nos Estados Unidos? A ideia era que vocês ficassem lá?

Cynara - Não foi uma temporada, nós fomos fazer um show na NBC, o Andy Williams Show, que era um programa de televisão, coast to coast, que abrangia os Estados Unidos inteiro, era o programa musical mais visto. O Andy Williams tinha feito o programa com o Marcos Valle antes da gente, fez com Caymmi, com o Tom [Jobim] e com o Quarteto em Cy. Fomos nós e o Marcos Valle juntos, e foi ótimo. Até hoje aquele clipe aparece nas redes sociais. Só que depois disso, não fizemos mais nada. Frequentamos casas importantes, de gente famosa, vimos shows, grandes músicos, pianistas de jazz e também alguns conjuntos vocais da época, de mulheres, de homens, conhecemos muita coisa.

DLS - Isso foi em [19]67, não?

Cynara - Aconteceu o seguinte: através do Aloysio, nós recebemos uma proposta para ficar nos Estados Unidos, mas eu e a Cybele, de cara, dissemos não. A Cybele tinha um namorado aqui, eu namorava o Ruy [Faria], do MPB4, e a gente pretendia se casar. Era um contrato longo, tudo lá era muito longo, porque se investia na carreira da artista. Eu disse: "eu não quero". Cybele também: "eu não quero". Aí acabou que ninguém quis, e nós voltamos em [19]67. O Chico Buarque era muito amigo do Ruy e era amigo nosso também, de encontrar; o conhecemos em [19]64, em São Paulo, através do Chico de Assis, em um show em São Paulo, junto com o MPB4. O Chico ia ver os ensaios todos os dias, e nos deu uma música, Pedro pedreiro, e deu outra para o MPB4. Nós lançamos a música; o MPB4 lançou também: Sonho de um carnaval.

Quando voltamos dos Estados Unidos, em [19]67, o Ruy falou assim: "o Quarteto vai voltar para os Estados Unidos e vocês?”. Eu e a Cybele resolvemos romper na cara dura: não vamos voltar para os Estados Unidos. Aí o Ruy falou assim: "Querem saber? Façam uma dupla", foi o Ruy que deu essa ideia, "façam uma dupla, vou falar com o Chico, ele tem música de festival". Ele disse e fez. O Chico falou: "eu tenho uma música ótima 
para elas, chama Carolina", e nós cantamos Carolina no festival³ de [19]67 e ficamos em terceiro lugar - em segundo lugar ficou Travessia ${ }^{4}$ e em primeiro ficou Margarida de Guttemberg Guarabyra. Nós ficamos muito amigas do Chico, fizemos um disco na Columbia, eu e a Cybele, e o Chico deu todas as coordenadas de repertório, e ainda escreveu a contracapa. O Chico ficou muito íntimo, queria namorar a Cybele, aquela história. Ele ia lá para casa - minha mãe veio para o Rio ficar com a gente, alugamos um apartamento em Copacabana. O Chico chegava e a minha mãe olhava pelo olho mágico e falava "é aquele moço", Cybele; "não, não abre não", ela dizia, porque ela não queria namorar o Chico de jeito nenhum. Mas saíamos muito juntos, todo mundo. Íamos para os boliches, madrugada adentro, ficávamos ali em Ipanema, no Arpoador, víamos o sol nascer. Nos anos 60, 70, foi liberdade total.

Em [19]68 o Chico tinha uma música do festival, Sabiá,5 falou: "vocês querem fazer Sabiá?". Claro que queríamos. Mas o Chico viajou, foi para a Itália, e o Tom nos ensaiava, eu e a Cybele, na casa dele, na Rua Codajás. Ensaiávamos Sabiá todos os dias, e fomos cantar no festival. Foi aquela vaia homérica, inesquecível. E o Chico estava fora, em Veneza nessa época. Esse momento foi o da passagem da parte nacional para a internacional. O Tom dizia: "o Chico tem que vir embora, tem que vir para cá, eu não aguento levar essa vaia sozinho". E o Chico veio para a final; subiram os dois ao palco com a gente, e então deu tudo certo. Nessa hora da final, o público tinha que torcer pela música do Brasil, então Sabiá ganhou e foi uma boa torcida. Mas na parte nacional, que nós disputamos com o Vandré, foi um horror, foi vaia que não parava mais. Foi uma tristeza e eu fiquei danada da vida, porque como é que pode vaiar uma música daquela e como que pode vaiar Chico e Tom? Não era por nós... a gente não entende muito esse país, essa coisa de não ver aqui e aqui, ${ }^{6}$ mas cada época tem sua razão de ser, as coisas têm sua razão de ser. $\mathrm{O}$ público queria a música do Vandré, porque falava do sentimento que o povo estava sentindo naquela hora, falava da repressáo. Valeu, valeu tudo e eu adoro o Vandré, inclusive, nós ficamos muito amigos, o Vandré é uma figura. Mas Sabiá está voando aí, até hoje.

DLS - Como foi ter passado por aquela situação no Festival, naquele momento? Havia tensão nos bastidores?

Cynara - Lembro mais ou menos, porque era tanta gente, principalmente por ser um festival internacional, tinha gente do mundo inteiro, Françoise Hardy, ${ }^{7}$ me lembro de

Festival Internacional da Canção (FIC), organizado pela TV Globo.

Composição de Milton Nascimento e Fernando Brant.

Composição de Chico Buarque e Tom Jobim.

Nesse momento, faz o gesto com a mão como se fosse um antolhos, destacando uma visão limitada.

7 Representante da França na etapa internacional que contou com 33 países concorrentes. 
algumas pessoas. A gente tinha uma patota, entende? Eu gostava muito de estar com as aquelas pessoas ao meu redor, eram amigos mesmo, gente amiga. Mas foi muita zona. No festival só ganha um, né? Segundo, terceiro... é aquela competição. Nós éramos muito ingênuas, eu e a Cybele, a gente se doava muito às pessoas, mas a gente também sabia que estava todo mundo querendo que a gente se danasse, porque todo mundo queria aquele lugar que a gente levou; mas isso também era normal. Lembro que teve muito perrengue em relação ao Vandré, ${ }^{8}$ estavam querendo tirá-lo antes de cantar. A política, eu vou falar um palavrão, a política é boa, mas é uma merda, entende? Quando você não entende para que serve a política, para onde ela vai, entáo é muito bom você ser um ser político, você saber se colocar, ter uma postura política, uma postura cidadã, isso eu acho bacana pra caramba. Agora, a política ideológica, eu tenho horror, horror. E o que está acontecendo no Brasil de hoje é isso, é uma coisa que ou você é isso ou você é aquilo, enquadrada. Eu acho isso insuportável, porque eu náo sou isso e nem aquilo, onde é que eu vou me inserir? Pelo amor de Deus! Principalmente partidariamente, não tem, não dá. Eu não tenho onde me inserir, sinceramente, eu não acho nada bom, nada, nada, nada, nada; sou uma pessoa e aí eu digo com minha boca cheia, totalmente independente, tenho o humanismo dentro de mim que é o que me salva. Eu sou uma pessoa que lida com os sentimentos, com as emoçóes, eu náo quero saber de politicagem. Eu tenho muitos amigos que pensam totalmente diferente de mim, mas são amigos, entấo eu procuro levar para o lado que eu os veja com alguma afinidade, eu preciso ver nas pessoas alguma afinidade, porque senão vai ser uma guerra, entende? Principalmente em redes sociais, onde nós temos que ter um cuidado danado. No começo eu me expunha muito. E me vi me autocensurando. Hoje eu tenho um lugar onde me inseri, vamos dizer assim, mas no começo eu sofri muito com patrulha, entende? Patrulha mesmo. Se você disser uma coisa que está fora do que aquela pessoa ou grupo considera correto, dança. Se você falar alguma coisa politicamente incorreta, dança. E eu sou totalmente politicamente incorreta. Eu sou, se eu tiver que dizer, eu falo, agora como eu tenho essa autocensura, por conta de eu ter levado muita porrada nas redes sociais, eu estou quieta, mas de vez em quando eu lanço, porque eu faço post falando sobre política, mas essa política que eu estou aqui falando, cidadã.

DLS - Essa questão da patrulha ideológica foi um pouco do que vocês passaram também durante a ditadura, porque vocês não eram a favor da ditadura militar.

Cynara - Sim, absolutamente, está louco! Deus me livre!

DLS - A música foi vaiada por uma patrulha ideológica também, naquele momento? 
Cynara - Ninguém viu que essa música do Chico e do Tom, Sabiá, é uma música inspirada num poema lindíssimo de Gonçalves Dias:9 "sei que ainda vou voltar para o meu lugar", aqui é meu lugar. Ninguém viu isso. Só que o Chico mesmo disse que náo fez aquilo para panfletar nada, aquilo foi poema, aquilo é totalmente lírico, assim como a música do Tom, é erudita, praticamente. Mas as pessoas queriam isso, queriam levar para esse lado, entende? Como o Chico náo foi panfletário nessa letra, preferiram o Vandré que estava na cara "Caminhando e cantando...". Adoro o Vandré e ele se prestou a isso. Eu e Cybele fomos para São Paulo, logo depois da Sabiá, e fizemos muitos programas dele na Bandeirantes, o Vandré tinha um programa dele, e nos convidou para cantar lá com ele. Nós conhecemos as músicas do Vandré mesmo, umas músicas lindas, parcerias dele com Carlinhos Lyra e com outros. E aí nós vimos que o Vandré não era nada daquilo, pegaram essa música e fizeram dela o panfleto da ocasião. Serviu a um propósito, principalmente porque o Maracanázinho, com 20 mil pessoas, precisava de uma pessoa regendo aquele momento e o Vandré se prestou a isso. Eu acho perfeito, ele era aquilo também, sentia aquilo. Hoje em dia o Vandré virou outra coisa que eu também não sei o que é. Nós o encontramos em Teresópolis, ele é um barato, ficou com a gente o tempo todo: "vamos tomar café juntos, vamos almoçar juntos”. Ele é uma pessoa extraordinária, inteligente. Só que ele estava num clima que eu não entendi. Fez uma música para a Força Aérea Brasileira, Fabiana é o nome da música, "vem cá que eu vou mostrar a Fabiana para vocês". Não dá para entender. Por isso que eu procuro separar um pouco essas coisas. Toda hora as pessoas perguntam: "e o Chico?”, "o Chico adora o Lula”. Vou dizer outro palavrão: “Foda-se”, está entendendo? O Chico é meu amigo, que eu amo, é o maior compositor brasileiro e ponto, o que ele quer para a vida dele é problema dele, eu não vou entrar nessa. E eu defendo o Chico até a alma, deixa ele ser o que ele é, ele é amigo dessas pessoas, ele viveu, a família dele é isso, o senhor Sérgio [Buarque de Holanda], a dona Maria Amélia, todo mundo fundou, ajudou a fundar o PT [Partido dos Trabalhadores], entáo deixa ele ser isso, porque é a vivência dele, e eu respeito pra caramba o Chico.

DLS - E como é a relação do Chico Buarque com o Quarteto em Cy?

Cynara - Maravilhosa, toda vez que eu ligava para ele, eu ligo muito pra ele: "Chico, vai participar do disco da gente?", "Qual é a música?”, ele só pergunta isso. Fizemos o Chico em Cy, eu liguei pra ele e falei: "Chico, nós vamos fazer um disco só de tuas músicas, o que você aconselha a gente a cantar? Ele falou: "ah... O futebol", 10 "mas $O$ futebol, uma música de homem?", "é, eu quero ver vocês quatro cantando $O$ futebol". Então tá, eu fiz o arranjo, eu adoro, uma música ótima, difícil pra caramba. Mas é isso,

\footnotetext{
9 O nome do poema é Canção do exílio.

10 Composição de Chico Buarque.
} 
o Chico é a paixão da vida da gente, é a minha paixão particular, apesar de ele ter se apaixonado pela Cybele.

Adrianna Setemy - Cynara, outro dia saiu uma matéria no $O$ Globo dizendo assim: "2018, 50 anos de Sabiá", e a matéria falava sobre o festival de 1968. Para você o que representa 50 anos de Sabiá?

Cynara - Para mim, a vida se divide em antes e depois de Sabiá. Eu estava lendo uma postagem que fizeram com a final do Sabiá, a gente cantando no último dia, lá no Maracanăzinho, dia 6 de outubro de 1968, o último dia da final do Festival Internacional. Aquilo foi um marco na minha vida, tanto é que as pessoas me reconhecem, a mim e a Cybele, que infelizmente já se foi, como as sabiás, entende? Foi uma coisa táo marcante, tâo linda na vida da gente, tão forte, que, para mim, minha vida, minha carreira enquanto cantora, artista, tudo antes é maravilhoso, claro, Vinícius, Caymmi, Quarteto em Cy em começo de carreira, tudo é maravilhoso, mas aquele momento foi o momento que marcou a minha vida particular, eu sou antes e depois de Sabiá. Depois disso, eu visualizei outra coisa na carreira do Quarteto, porque apesar de termos sido uma dupla que saiu de dentro do Quarteto, o Quarteto em Cy pegou a sobra disso, e foi uma sobra maravilhosa. Hoje em dia nós fazemos shows e as pessoas pedem: "Sabiá, Sabiä". Nós temos um arranjo da Sabiá do Quarteto, que nós cantamos uma vez ou outra, náo sempre, porque me incomoda náo ter a Cybele perto de mim, ${ }^{11}$ me incomoda de saudade, mas a gente canta de vez em quando. Há pouco tempo, eu e a Cyva fizemos a Sabiá porque a Luciana Medeiros nos convidou para cantar na sala Cecília Meirelles. Foi lindo, foi um programa que chamava 68 no Mundo, ${ }^{12}$ na França e no Brasil. E no Brasil, a marca foi a Sabiá de [19]68. Eu e a Cyva cantamos com uma grande orquestra da [Fundaçáo] Cesgranrio, o público veio abaixo, de pé, todo mundo aplaudindo. Voltar a cantar com orquestra essa música, não com a Cybele, mas com a Cyva, minha outra irmá, que faz parte do Quarteto até hoje, foi a glória.

DLS - Em 1969 você grava seu único disco solo, que é o disco da Elenco, fale um pouco deste disco, que foi o Sidney Miller que produziu, não foi?

Cynara - Foi, foi o Sidney, mas o Ruy, que era meu marido na época, era muito presente na minha vida, então ele foi o diretor musical do disco, mas o Sidney produziu e fez os arranjos. Inclusive, tem música minha e do Ruy com o Sidney, que é a Oração do astronauta, ${ }^{13}$ que é linda, é uma valsa bonita mesmo. O Sidney é um gênio, meu

\footnotetext{
11 Cybele faleceu em 22 de Agosto de 2014, na cidade do Rio de Janeiro, aos 74 anos.

12 O nome do evento é Maio de 68 - 50 anos depois.

13 Referência ao box com três CDs lançado pelo selo Discobertas com showes do Quarteto em Cy das décadas de 1960 e 1970.
} 
compadre. Eu digo compadre porque eu e ele, e a mulher dele e o Ruy, nós fomos padrinhos de casamento do Guarabyra com a Guaíra, entáo ficamos padrinhos e começamos a chamá-los de compadres. A gente saía junto o tempo todo, a Jeanne [Marie], mulher do Sidney, comigo e o Sidney, a gente saía muito para tomar chopp à noite, era a época da gandaia, aqueles anos que deixaram marcas, enfim. O que eu acho a maior injustiça desse mundo é o Sidney não ter o reconhecimento devido, eu acho que o Sidney é um gênio, é um pensador, um cara que pensava o país com liberdade, de pensamento e de açáo. E era uma turma boa, Guarabyra, meu amigo pessoal até hoje. Essa época eu vivi com muita força, os anos 60, 68, 69, até 70. Depois, a Cyva ficou nos Estados Unidos, refez o Quarteto lá. Em [19]72 ela voltou, e a gente o refez aqui, o Quarteto em Cy. Nós passamos por muitas mudanças de componentes, mas sempre com uma marca muito forte que a gente preza: a marca musical, do bom gosto do repertório, de procurar letra certa, harmonia, essa coisa ninguém tira da gente.

DLS - E como vocês escolhem o repertório?

Cynara - Nossa democracia funciona assim: só gravamos quando todas querem, porque se uma não gosta a gente vai gravar por quê? Já é uma coisa puxando para trás, eu penso assim. Para chegar a um consenso a gente vota, vota, vota, vota, até chegar na música que todo mundo gosta. É uma democracia absoluta.

DLS - Como foi a relação do Quarteto em Cy com o MPB4?

Cynara - Eu fui casada com o Ruy e tenho três filhos com ele. Carreiras paralelas. Nessa caixa tem um disco, que eu acho que é o principal do box: ${ }^{14}$ é o primeiro show que nós fizemos com o MPB4, no Zum-Zum, de direção de Aloysio de Oliveira. É um show ao vivo. O Marcelo Froes começou a resgatar coisas; eu digo: "eu tenho um show aqui, mas eu acho que está mal gravado", "quero ouvir tudo", ele diz. Como resultado, ele remasterizou, mixou, tirou isso, tirou aquilo. E eu, a Cyva e ele fizemos uma parceria muito boa nesses discos, porque nós escrevemos as coisas, está tudo lá explicadinho nos encartes. O que eu gosto no $\mathrm{CD}$, muito melhor do que ficar baixando música, que é um saco, é que você lê, você pega. Eu gostava do LP, mas hoje virou aquele dinossauro, tudo bem. Mas o CD tem que ter o encarte, você pode ouvir e ler a letra; tem informaçóes das pessoas, dos artistas, dos compositores, que são coisas pouco valorizadas hoje. Tem que ter o nome das pessoas que fizeram a composição, não só de quem está cantando, quem está cantando é um veículo, assim como a gente grava música de todo mundo.

14 Nesse momento faz referência a um quadro com a foto de Vinicius de Moraes que está na sala de sua casa, onde a entrevista foi gravada. 
DLS - Qual foi a participação do Quarteto em Cy no disco dos Afro-sambas, emblemático na música brasileira?

Cynara - Total! Afro-sambas foi outra história interessante. Vinícius chamou o Quarteto em Cy para fazer os Afro-sambas com o Baden [Powell], eram as músicas do Baden com letra do Vinícius, e orquestraçóes fantásticas de Guerra-Peixe, esse cara era o bambambã, maravilhoso. Na hora de gravar, o Wadi Gebara e o Roberto Quartin, da Forma, disseram que tinha o horário tal, dia tal, para gravar no estúdio tal. Nós tínhamos show em São Paulo e dissemos aos Vinícius que não podíamos naquela data. O Vinícius falou assim: "ah, não pode?”. Aí o Gebara, ou foi o Quartin, que sugeriu outro coro. E o Vinícius disse que não: "muda a data, eu quero elas". Eu falei "Vinicius..." eu tenho que colocar uma foto desse homem na parede!15 Esse cara foi o cara que realmente deu vida ao Quarteto, não posso deixar de reconhecer. Aí está cheio de lembranças, tudo quanto é lugar que você pegar tem um livro do Vinícius. Ainda demorou mais um dia, porque caiu uma chuva no Rio de Janeiro que alagou tudo, tivemos que esperar mais um dia. Mas nós gravamos. O Vinícius levou o coro para cantar com a gente e ficamos danadas da vida porque era um coro desafinado e a gente cantando junto: "vão dizer que é a gente". E o Vinícius: "não, todo mundo sabe". Foram perrengues engraçados e que fazem parte da rotina de quem vive de música.

DLS - O que a gente tem visto em pesquisas é que muitas pessoas tentam enquadrar os artistas em gêneros musicais e os artistas não "enquadráveis", são, às vezes, deixados de lado. Como você vê essa questão em relação ao Quarteto em Cy?

Cynara - A gente faz de tudo um pouco, a gente gravou Gil e Caetano em Cy [1999], a gente gravou bastante MPB, gravamos muita Bossa Nova de Tom e Vinícius, Jackson do Pandeiro. É tudo música brasileira; não acaba, não tem fim aqui. Custódio Mesquita, Fernando Lobo, Noel Rosa. Não tem que ficar colocando em escaninho, eu não suporto isso, sinceramente. Nós somos cantoras de música brasileira: quer botar MPB, bota, quer botar Bossa Nova, bota também, entendeu? Bota tudo! A gente canta tudo, no show da gente, a gente canta de Maria, Maria, ${ }^{16}$ do Milton Nascimento, a Querelas do Brasil. ${ }^{17}$

DLS - Vamos voltar ao disco solo Pronta para consumo, de 1969: você escolheu o repertório, você já tinha feito composiçôes, gravado suas próprias composiçôes, ou aquele foi o primeiro disco, como foi esse processo?

15 Nesse momento faz referência a um quadro com a foto de Vinicius de Moraes que está na sala de sua casa, onde a entrevista foi gravada.

16 Composição de Milton Nascimento e Fernando Brant.

17 Composição de Maurício Tapajós e Aldir Blanc. 
Cynara - Foi o único disco meu. A Cyva ficou nos Estados Unidos, casada com o Aloysio de Oliveira e ela chamou a Cybele, quer dizer, ela desfez a minha dupla, e eu fiquei danada da vida. A Cybele estava casada com o Marcílio e foram os dois morar lá, porque o Marcílio foi trabalhar na embaixada do Brasil nos Estados Unidos e a Cybele refez, com a Cyva, a Regina, que estava no Quarteto e era esposa do Oscar Castro Neves, e mais uma moça, um outro Quarteto, o Quarteto em Cy de lá. E eu fiquei aqui sozinha. Em 1970 eu tive o meu primeiro filho, entáo eu estava muito agoniada. A Cybele foi embora, o Quarteto parou e eu vou ter um filho. E a música, onde fica nisso? E alguém me deu a ideia de fazer um disco, acho que foi lá na própria Polygram, na Philips, gente lá de dentro: "vamos fazer um disco?", "mas eu sozinha?", "você sozinha". Como eu era muito amiga do Sidney, eu o chamei: "Sidney, vamos fazer?", "vamos fazer". O Ruy, que era meu marido, era do MPB4, deu pitaco também, fizemos músicas juntos, e foi uma coisa fácil de fazer, não foi difícil, porque quando você é um cantor solo, você é dono da sua vida, você faz o que você quer, não deve satisfação. E com o Quarteto, você já tem que se adequar, o repertório tem que ser o que todo mundo gosta, o que todo mundo quer. Eu inventei um repertório nesse disco que eu gostava. Claro que eu ouvi o Sidney, dicas do Ruy, do Guarabyra, que é maravilhoso, adoro Guarabyra, o Renatinho [Corrêa] dos Golden Boys, que também está nesse disco, na produçáo. Foi uma turma boa, a gente ia lá para casa, eu morava no comecinho de Copacabana e minha casa era frequentada pelo pessoal de Minas, era Guarabyra, Milton Nascimento, o Maurício Maestro ia muito lá, era um pessoal ligado em música de essência mesmo. Na hora de escolher, fomos botando as coisas e o Sidney era muito ligado em música antiga, tanto é que tem uma música que eu canto, que é de J. Cascata, Nosso romance, ${ }^{18}$ é linda. E eu adorava essas coisas, porque a minha mãe, no interior da Bahia, cantava isso, entáo tinha tudo a ver, entende? Ao mesmo tempo, tinha uma música do Caetano, que era Deus vos salve esta casa canta, ${ }^{19} \mathrm{Chico}$, tinha tudo, esse LP é um saco de gato, mas era o que estava rolando na época, na minha cabeça. Eu tinha que gostar e tinha que ter a minha turma me apoiando. Foi um disco em conjunto, acho que esse disco não é meu só, é muito de Sidney. É um disco coletivo, porque o Sidney deu muita dica, muita, muita, fez arranjo, inclusive. O Ruy canta um pedacinho comigo no Umas e outras, ${ }^{20}$ no finalzinho. Entáo eu devo esse disco a esses amigos, como uma força que eles estavam querendo me dar: "vamos cantar, vamos cantar", vamos lá. Nós íamos para o Lula Bar, ali em Ipanema, eu frequentava esses lugares, era da night, vamos dizer, sempre fui, mas teve uma hora que eu tive que parar.

\footnotetext{
18 Composição de J. Cascata e Leonel Azevedo.

19 Composição de Caetano Veloso e Torquato Neto.

20 Composição de Chico Buarque.
} 
DLS - Como vocês se relacionavam com as gravadoras? Vocês passaram por várias gravadoras.

Cynara - Pessimamente. Gravadora é igual editora, é igual a tudo, né? Tem o poder, entáo você tem mais ou menos que lidar com isso. Apesar de que, vou dizer a verdade: nós demos muita sorte de ter, nas gravadoras, pessoas sensíveis. Por exemplo, na Universal a gente tinha o [Roberto] Menescal, tinha Paulinho Tapajós, que foram produtores do Quarteto. Eram pessoas que ouviam a gente, sabiam que a gente gostava de harmonia. $\mathrm{Na}$ Som Livre, nós fizemos o Caminhos cruzados - Caymmis, Lobos e Jobims [1981], que foi o [Eduardo] Athayde, ótimo produtor também. Na CID, que é uma gravadora pequena, que você não dá nada, mas é ótima, nós gravamos muitos discos através do Esdras Pereira, que é um produtor que "vamos gravar, vamos gravar", pessoas incentivadoras, nós tivemos essas pessoas. Agora, em se tratando do que a gravadora propóe para o artista, aí é aquele negócio: poder. O Quarteto nunca foi vendedor de discos, nunca. O sucesso da gente é um sucesso de prestígio, nós construímos a carreira degrau por degrau, sem ouvir que tínhamos que fazer concessáo, nunca, nunca. Para as gravadoras, nós éramos um entrave, nós não servíamos para elas, eles tocavam a gente para frente, porque eles sabiam que a gente tinha um público fiel, que é fiel até hoje. O público quer ouvir, entende? Gravadora é uma coisa de dois lados. Mas nós não estávamos nem aí, estávamos focadas no trabalho.

DLS - E o papel da televisão na carreira de vocês?

Cynara - A mesma coisa: o grande poder da mídia, assim como jornais, nós nunca valorizamos isso mais do que o valor que tem, entende? Tem valor? Claro que tem, mas se extrapolarmos e acharmos que aquilo ali é que vai dar um rumo na vida da gente, dançamos. Se eu ficar pensando: "poxa, eu não estou na Globo, o Faustáo não me chamou, nunca mais a gente fez...”, foda-se de novo, está entendendo? Aí eu sou totalmente Dercy Gonçalves. Não quero saber, a gente vai continuar o trabalho, o caminho que a gente traçou, não faço a menor questão de estourar na televisão, porque eu sei o que é estourar na televisão, eu sei exatamente o que é que a televisão quer. Os jornais não, eu adoro jornal, adoro pegar no jornal, meu pai tinha um jornal no interior, minha irmá mais velha escrevia, eu ia para a tipografia com meu pai, nunca me esqueço, era louca pela engrenagem do jornal. Então eu via as coisas nascerem, eu era muito criança, eu dou um valor danado a jornal, à informaçáo. E quando eu vejo, hoje em dia - aí eu quero fazer um agrave -, quando eu vejo hoje em dia pessoas darem pau total na Globo, nos jornais, n'O Globo, nos jornais todos; se a gente não ouvir isso tudo, ouvir tudo, ver e ouvir tudo, a gente não vai ter referência nem para dizer que é uma porcaria, tem que ouvir, tem que saber, tem que ler, tem que se informar de todas as maneiras. Eu náo me oponho a ler nada, a ver nada, a ouvir nada, eu estou sempre ligada nas coisas. Agora eu estou vendo uma juventude assim: "eu não vejo, você vê isso, você lê isso, você lê a Veja, você lê $O$ Globo, você vê a TV Globo, a Globo News, é tudo uma porcaria”. Não. Altos profissionais fazendo isso. A ideologia das mídias é outra coisa, você tem que ver para fazer sua visão crítica, 
mas depois que você se informar, ver aquilo, entender e sacar, eu sou dessa teoria. Eu sou libertária, completamente. Eu sou uma pessoa a favor da liberdade de expressão total.

DLS - Para finalizar, eu gostaria que você falasse do Quarteto em Cy hoje.

Cynara - Muito feliz, porque chegamos numa fase do Quarteto que não se cobra mais, a gente não se cobra entre si, entre Cys. Vamos fazer o que a gente gosta cada vez mais, isso não é de agora, isso já tem um tempo, porque o Quarteto passou por muitas fases de fracassos, de sucessos, e isso dá respaldo para gente quando chega a hora, para a gente escolher exatamente aquilo que quer, nem mais, nem menos. O Marcelo Froes, da Discobertas, está fazendo um trabalho lindo, não só com o Quarteto em Cy, com a Nara [Leão], com vários artistas. Ele está pegando os shows que não tiveram gravaçóes em LP, em CD, e resgatando isso de fitas magnéticas e está colocando em CD e vendendo isso, jogando isso na praça. Foi o que acabamos de fazer, que é o box do Quarteto, que é esse aqui, maravilhoso, que eu completamente recomendo, que são três CDs de fases distintas, décadas de [19]60 e [19]70, dois dos anos [19]60, de [19]65 e de [19]66, e outro de 1975. O de [19]65 é a glória, porque é um disco que tem o Quarteto em Cy com o MPB4, um show que gravamos em [19]65 e éramos muito jovens. Aquiles, se eu não me engano, tinha 17 anos, Cylene, a minha irmá mais nova, tinha 18, eu tinha 20, estou dizendo minha idade já, eu tinha 20 em [19]65, então agora tenho 73 anos, estou feliz da vida. E aí a gente vê que é uma garra, um show lindo, dirigido por Aloysio de Oliveira, tinha Rosinha de Valença também, com o conjunto de Oscar Castro Neves. É lindíssimo e eu recomendo, porque não é volta ao passado, dali a gente tira exemplos de grandes vocais, grandes sonoridades.

AS - Se você puder contar rapidinho aquela história que você falou para gente de uma turnê com o Vinícius, em que teve um caso de censura...

Cynara - Ah, foi! Foi em [19]74, nós fizemos a turnê com o Vinícius saindo de São Paulo, Rio de Janeiro, indo para Brasília e de lá íamos para Manaus. Quando chegou em Brasília, éramos nós, o Toquinho e o Vinícius e uma banda pequena de três músicos. O Vinícius durante o show, recitava um poema sobre o ano de 1973: "o ano triste e sem sorte, esse de 1973, levou para o cemitério três Pablos de uma só vez, Neruda, Casals e Picasso...”. No final ele dizia: "o ano triste e sem sorte, vá para a puta que pariu". No que ele falou isso, o povo ficou em polvorosa naquele ginásio em Brasília. E não deu outra: no dia seguinte vetaram o Vinícius, censuraram o Vinícius, um poeta, um puta de um cara. Então o que aconteceu: nós continuamos a viagem e ele deveria voltar para o Rio. Mas ele falou: "não senhor, vou com vocês". Foi até Manaus com a gente, na turnê toda. Nos teatros, eram grandes teatros, ele ficava nas coxias e a gente cantava olhando para ele, propositalmente, nunca esqueço. Em Recife a gente cantando Por causa de você21 para ele, viradas todas as quatro, e era uma música

21 Composição de Tom Jobim e Dolores Duran. 
à capela, só vozes, e ele lá todo feliz. Aí o público entendeu, levantou-se: “entra, entra, entra”, querendo que ele entrasse. A gente pensava: "não pode, não pode entrar, senão vai dar um galho danado", ele estava proibido pela censura, vão prender. Aí ele ficava lá na coxia, se balançando todo. Foi uma temporada linda, linda, linda. E o Vinícius é... não dá para descrever o que foi o Vinicius na vida da gente.

DLS - Isso mostra que a censura não tinha limite nenhum.

Cynara - Não tinha limite. Um poema. Um poema que o cara fez para três Pablos, os grandes Pablos: Picasso, Casals, um puta músico, Neruda. Era um show lindíssimo. Esse show, inclusive, foi organizado por ele, Toquinho e a gente em Sáo Paulo, começou no Tuca [Teatro da Universidade Católica] de São Paulo, e quem deu as coordenadas foi Gianfrancesco Guarnieri. Cantávamos músicas latinas, Violeta Parra, Mercedes Sosa, lindo! É uma pena, porque não foi um show completo até Manaus. A gente deixava a mesa dele com o copinho de uísque para dizer que ele estava ali e ele na coxia, foi emblemático, completamente.

DLS - Obrigado.

AS - Muito obrigada por recontar essa história.

\section{Referências}

PATAI, Daphne. História oral, feminismo e politica. São Paulo: Letra e Voz, 2010.

PORTELLI, Alessandro. História oral como arte de escuta. São Paulo: Letra e Voz, 2016.

SARAIVA, Daniel. Cynara em Cy. IMMuB: Instituto Memória Musical Brasileira, Rio de Janeiro, 16 jan. 2021. Disponível em: https://immub.org/noticias/cynara-em-cy. Acesso em: 20 mar. 2021.

Recebido em 10/04/2021.

Aprovado em 19/04/2021.

Contribuiçóes dos autores: Saraiva: roteiro, gravação do depoimento, texto de apresentação e pesquisa bibliográfica; Setemy: gravação do depoimento e roteiro; Knack: gravação do depoimento e roteiro.

Fonte de financiamento: nada a declarar.

Conflitos de interesse: nada a declarar. 